Canadian

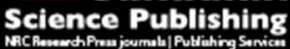

Environmental Reviews Dossiers environnement

\title{
A Comparison of Metrics to Evaluate the Effects of Hydro- facility Passage Stressors on Fish
}

\begin{tabular}{|r|l|}
\hline Journal: & Environmental Reviews \\
\hline Manuscript ID & er-2016-0006.R2 \\
\hline Manuscript Type: & Review \\
\hline Date Submitted by the Author: & 15 -Jul-2016 \\
\hline Keywlete List of Authors: & $\begin{array}{l}\text { Colotelo, Alison; Pacific Northwest National Laboratory } \\
\text { Goldman, Amy; Pacific Northwest National Laboratory } \\
\text { Wagner, Katie; Pacific Northwest National Laboratory } \\
\text { Brown, Richard; Pacific Northwest National Laboratory } \\
\text { Deng, Z.; Pacific Northwest National Laboratory } \\
\text { Richmond, Marshall; Pacific Northwest National Laboratory }\end{array}$ \\
\hline & hydropower, fish, survival, metrics, injury \\
\hline
\end{tabular}

\section{SCHOLARONE \\ Manuscripts}




\section{Stressors on Fish}

3 Alison H. Colotelo*, Amy E. Goldman, Katie A. Wagner, Richard S. Brown, Z. Daniel Deng, Marshall C.

4 Richmond

5

6 Earth Systems Science Division, Pacific Northwest National Laboratory, Richland, Washington, 99352

7 USA

8

9 *Corresponding Author: 902 Battelle Boulevard, MSIN K7-70, Richland, Washington, 99352; Phone:

10 509-371-7248; Fax: 509-371-7397; Email: Alison.Colotelo@pnnl.gov 


\section{Abstract}

Hydropower is the most common form of renewable energy, and countries worldwide are considering expanding hydropower to new areas. One of the challenges of hydropower deployment is mitigation of the environmental impacts including water quality, habitat alterations, and ecosystem connectivity. For fish species that inhabit river systems with hydropower facilities, passage through the facility to access spawning and rearing habitats can be particularly challenging. Fish moving downstream through a hydrofacility can be exposed to a number of stressors (e.g., rapid decompression, cavitation, blade strike and collision, turbulence, and shear forces), which can affect fish survival in direct and indirect ways. Many studies have investigated the effects of hydro-turbine passage on fish; however, the comparability among studies is limited by variation in the metrics and biological endpoints used. Future studies investigating the effects of hydro-turbine passage should focus on using metrics and endpoints that are easily comparable. This review summarizes four categories of metrics that are used in fisheries research that have application to hydro-turbine passage (i.e., mortality, injury, physiological markers, behavior) and evaluates them based on several criteria (i.e., resources needed, invasiveness, comparability among stressors and species, and diagnostic properties). Additionally, these comparisons are put into context of study setting (i.e., laboratory vs. field). Overall, injury and physiological markers are ideal for studies in which there is a need to understand the mechanisms of effect, whereas behavior and mortality metrics provide information on the whole body response of the fish. The study setting strongly influences the comparability among studies. In laboratory-based studies, stressors can be controlled by both type, intensity, and duration, allowing for easy comparisons among studies. In contrast, field studies expose fish to realistic passage environments but the comparability is limited. Based on these results, future studies, whether lab or field-based, should focus on metrics that relate to mortality for ease of comparison, while some diagnostic capability is important for furthering the science. 
37 Hydropower is the most heavily relied upon source of renewable energy in the world, accounting for over $38 \quad 16 \%$ of total electricity generation (International Energy Agency 2015). The reliance on hydropower is

39 increasing with pushes to develop additional hydro-systems, including in some of the largest rivers in the 40 world (e.g., Amazon River [South America], Mekong River [Asia], Congo [Africa]; Zarfl et al. 2015,

41 Winemiller et al. 2016). With the prospective expansion of hydropower across the globe, it is critical to understand the environmental implications, including the potential for negative effects on fish during downstream hydro-facility passage.

As fish pass downstream through hydro-facilities, they can be exposed to a number of stressors (e.g., rapid decompression, cavitation, blade strike and collision, turbulence, and shear forces [Čada 2001]).

47 The magnitude of the stressor to which a fish may be exposed is dependent upon a number of variables

48 including turbine design and operations. For example, the Electric Power Research Institute (EPRI)

49 found that the ratio of the fish length to blade thickness is an important factor in determining the

50 likelihood of survival for fish struck by a turbine blade and that survival increases as the ratio of fish

51 length to blade thickness decreases (EPRI 2007, 2008, 2011). With regard to turbine operations, higher

52 discharge rates through turbines typically result in lower and more variable nadir pressures (the lowest

53 pressure that a fish experiences during passage) than those recorded in turbines operated using lower

54 discharges (Deng et al. 2010; Trumbo et al. 2014), thus affecting the range of pressures a fish

55 experiences. Once a turbine is installed within the dam, its design cannot be altered, but because turbine

56 operations change depending on the river conditions (e.g., percentage spill, headgate configuration, etc.),

57 the magnitude of stressors can fall across a range.

59 The type of response from an individual fish exposed to a stressor in a hydro-facility environment varies

60 and is dependent upon the type, intensity, and duration of the stressor (defined as an external stimulus or 
61 event that causes a physical, chemical and/or mental response inside of the body) as well as structure of

62 the fish (see Coutant and Whitney 2000 for a summary of fish behavioral responses). For example,

63 Brown et al. (2014) summarized the various traits that can influence the susceptibility of fish to

64 barotrauma due to rapid changes in pressure. Although the presence of an inflated swim bladder (or other

65 undissolved gases in the body) was determined to be the most important variable in predicting the

66 susceptibility of a fish to barotrauma, the type of swim bladder, depth of neutral buoyancy, life stage,

67 migration patterns, and structural integrity can also be important (Brown et al. 2014). In many river

68 systems, a variety of species and life stages of fish may be entrained into hydro-facilities. Therefore,

69 multiple thresholds for injury or mortality may need to be considered in the design of hydro systems to

70 account for the diversity of species and their respective susceptibility to effects from hydro-facility

71 passage.

Many field and laboratory based studies have been conducted to evaluate the effects of exposure to hydrofacility passage (e.g., survival studies) or isolated stressors on fish (e.g., rapid decompression, blade strike). However, methodology and biological endpoints can vary considerably among these studies, which makes it difficult to compare results across stressors and a wide variety of species (Pracheil et al. 2016). Therefore, there is a need to identify a metric(s) that can be used to assess the effects of exposure to the variety of different stressors inside a hydro-facility environment. Use of a standard metric that provides a quantitative value for the physiological state of a fish following exposure to any stressor or combination of stressors will allow for integration of dose-response data across studies. Additionally,

81 few studies (see Brown et al. 2012, Colotelo et al. 2012 for barotrauma relationships to simulated turbine

82 exposures) have evaluated fish along a broad range of exposure doses (i.e., magnitude of the stressor),

83 which limits the transferability of results to other hydro-facilities. For that reason, studies should be

84 conducted to encompass a wide range of doses that fish may encounter during downstream passage 85 though hydro-facilities. 
87 The objective of this manuscript was to compare and evaluate the metrics available to assess the effects of 88 hydro-facility passage on a wide variety of species and life history stages of those species. This review

89 first summarizes the stressors that fish may experience during downstream passage at hydro-facilities, 90 including hydro-turbines, spillways, sluiceways, and other passage routes. Next, is a summary of various 91 metrics (standards for measuring or evaluating) used to assess the health of fish and how these metrics

92 have or could be applied to evaluate the response that fish have to stressors during passage at hydro-

93 facilities. We conclude by discussing the advantages and limitations of the metrics presented based on 94 their cost, invasiveness, diagnostic properties, and comparability among stressors and species. We will 95 also discuss the applicability of the available metrics for use with design tools such as the Biological 96 Performance Assessment (BioPA) tool (Richmond et al. 2014) and evaluation tools such as Hydropower 97 Biological Evaluation Tools (HBET; Hou et al. 2015) and make recommendations on the metrics that 98 should be used for future studies that examine the effects of downstream passage through hydro-facilities.

Stressors

\section{Rapid Decompression}

101 Barotrauma is defined as trauma or injuries to body tissues that result from changes in barometric 102 pressure (Brown et al. 2012). Fish that pass through hydro-turbines or over spillways are at risk for rapid 103 decompression either due to nadir pressures on the backside of the turbine blade or by being quickly

104 brought up to surface pressure in the tailrace. The large decrease in pressure leads to an inversely 105 proportional increase in the volume of any existing gases within the body cavity. This relationship is 106 governed by Boyle's Law, which states that $P_{1} \times V_{1}=P_{2} \times V_{2} \mathrm{~V}_{1}$ (where $P_{1}$ and $V_{1}$ are the initial pressure 107 and volume and $P_{2}$ and $V_{2}$ are the resultant pressure and volume; Brown et al. 2012). Based on this 108 relationship, as the ratio of pressure change (acclimation pressure / exposure [nadir] pressure) that a fish 109 experiences during passage increases, the volume of undissolved gases also increases, which leads to 110 greater potential for barotrauma. Common injuries that are observed in fish exposed to rapid 
111 decompression associated with hydro-turbine passage include swim bladder over-inflation or rupture,

112 emboli in the fins and gills, hemorrhaging, and exophthalmia (as reviewed by Brown et al. 2014).

\section{Cavitation}

114 Cavitation is the formation of vapor cavities in a liquid (e.g., river water) and can occur when the liquid is 115 subjected to rapid decompression. These vapor cavities, or bubbles, can collapse violently, resulting in a 116 shock wave that can damage both fish and turbine structures. In the past, it was believed that cavitation

117 was the most important source of injury and mortality for juvenile fish that passed through hydro-turbines 118 (Muir 1959). However, further research has shown that cavitation occurs when the pressures drop below 119 the vapor pressure of water (approximately $2 \mathrm{kPa}$ ), which is rare for many turbines (Abernethy et al. 120 2001). While turbines are typically designed to minimize the likelihood of cavitation, fish may still be 121 exposed to cavitation. Muir (1959) documented that cavitation can result in hemorrhaging of the eyes and 122 gill plates and even death, but the response of fish to these forces has been largely unstudied (Pracheil et 123 al. 2016).

\section{Blade Strike and Collision}

125 Fish that pass through hydro-turbines must pass by turbine blades as the turbines rotate to produce 126 electricity, and thus are at risk of being struck by the leading edge of the turbine blade. The likelihood of 127 blade strike is dependent upon many physical and biological factors including turbine type, the number of 128 blades, blade length, blade width relative to fish length, turbine runner rotational speed, force of the 129 impact, fish length, and fish tissue sensitivity and flexibility (summarized in Deng et al. 2007). The 130 orientation of fish that are struck by turbine blades is largely unknown; however, many laboratory studies 131 have focused on blade impact with the broad side of the fish as it has the greatest surface area and so the 132 highest likelihood of occurrence (Cook et al. 2003). Injuries typically observed in fish exposed to blade 133 strike are scale loss, lacerations, abrasions, hemorrhaging, bruising, and eye damage (Turnpenny 1998). 
135 In addition to coming into contact with the turbine blades, fish may collide with other hydro-facility

136 structures during downstream passage. Structures include the turbine runner, wicket gates, stay vanes,

137 draft tubes, and spillways. Collision may occur due to disorientation of the fish or the inability of the fish

138 to swim against the current and being pushed into structures. Due to the similarities between injuries

139 from blade strike and collision, many studies that have investigated the effects of blade strike on turbine-

140 passed fish have likely included injuries due to collision with other structures in their analyses. As such,

141 many of the injuries typically observed in fish exposed to blade strike are relevant to those that collide

142 with other structures in the hydro-turbine environment (Cook et al. 2003).

143 Turbulence

144 Turbulence during hydro-facility passage can influence the behavior of a fish, potentially resulting in

145 disorientation. This disorientation may increase the likelihood of the fish colliding with structures in the

146 turbine, and may also influence their ability to survive the tailrace environment (Čada 2001).

147 Specifically, disorientation of a fish may result in increased susceptibility to predation in the tailrace

148 (Blackwell and Juanes 1998; Neitzel et al. 2000). Although the direct effects of turbulence may not be

149 lethal, there is little known about turbulence intensity (Gordon et al. 1992) and how that relates to a fish's

150 ability to navigate through the hydro-turbine and tailrace environments.

\section{$151 \quad$ Shear Forces}

152 Shear forces during downstream passage at hydro-facilities are created when two masses of water, that are

153 moving at different velocities, intersect or when water slows near a solid structure, a turbine blade, blade

154 runners, or wicket gates (Čada et al. 2007). The effects of shear forces on turbine-passed fish have not

155 been extensively studied for many species; however, effects are species-dependent and seem to vary with

156 the orientation of the fish (Neitzel et al., 2004). Injuries can include descaling, lacerations, bruising,

157 damage to eyes and operculum, and decapitation (Deng et al. 2005; Čada et al. 2007). 


\section{Mortality}

160 Mortality is one of the most common and simplest metrics used to assess how fish respond to downstream 161 passage through hydro-facilities. Depending on the requirements of the study, mortality can be assessed 162 immediately to determine the direct effects of exposure or after a prescribed period of time to include any 163 delayed mortality. Monitoring mortality can be minimally invasive to the fish, if fish that survive are 164 permitted to continue their natural life after the experiment is over, and can be easily assessed. However, measuring mortality alone has a low diagnostic capacity because causes of mortality are rarely identified.

167 Mortality assessments can be conducted in both laboratory and field environments. Researchers

168 conducting laboratory studies have exposed fish to stressors that simulate specific conditions that are 169 found in the large Kaplan turbine environment (e.g., Abernethy et al. 2001, Neitzel et al. 2004, Brown et 170 al. 2012, Deng et al. 2012) or have passed fish through reduced scale turbines to encompass multiple 171 stressors (e.g., Cook et al. 2003). Following controlled exposures in test apparatuses, researchers have 172 either released the fish into a natural river environment (e.g., Brown et al. 2013) or have held fish in a

173 laboratory setting and monitored immediate and delayed mortality (e.g., Davis and Ottmar 2006; Čada et 174 al. 2007; Colotelo et al. 2012). Laboratory studies are controlled, allowing researchers to isolate specific 175 stressors and sources of injury and mortality; however, holding conditions may not be representative of 176 what the fish experience in the wild (e.g., predation).

178 Field studies require the ability to recapture or remotely monitor tagged fish to determine their fate post179 passage. The development of tags that inflate post-passage, such as the Hi-Z Turb'N Tag (Heisey et al. 180 1992), allows researchers to release fish directly into specific passage structures in the dam and recover 181 those individuals in the tailrace of the dam (e.g., Mathur et al. 1996). These fish can then be examined for 182 the presence of injuries and held to monitor mortality (typically up to 48 hours). Similarly, some studies 
183 have collected fish in the tailrace environment using nets to assess injuries and mortality (e.g., Taylor and

184 Kynard 1985; Navarro et al. 1996). The advantages of recapture studies include the ability to expose fish

185 to multiple stressors and to examine individuals immediately after exposure.

187 Run-of-the-river fish bearing transmitters can also be used to assess hydro-facility mortality rates. In

188 these studies, fish are typically released several kilometers upstream of a dam to allow them to become

189 acclimated to the river, and are allowed to pass volitionally through the dam, including all available

190 passage routes (known as a virtual release; Skalski et al. 2010). Active telemetry systems (i.e., acoustic or

191 radio) are used in these studies to determine the route of passage and estimate the mortality rates of fish

192 (e.g., Stier and Kynard 1986; Metcalfe et al. 1997; Wertheimer 2007). This method is advantageous as

193 fish are more likely to approach and pass the hydro-facility in similar ways to untagged individuals;

194 limiting bias with study results. However, it has the disadvantage that it is sometimes difficult to parse

195 effects of damage incurred by a particular stressor.

\section{Injury Assessment}

197 In its simplest form, injury assessment after exposure to a stressor is an external and/or internal visual

198 assessment of any injuries present, which frequently includes necropsy, and imaging techniques such as

199 x-rays, magnetic resonance imaging (MRI) and computed tomography (CT) common in medical

200 applications as well as standard photography. Many forms of visual assessment do not require costly

201 instrumentation or analyses and so it is widely used as a way to determine the impacts of different

202 stressors, particularly in studies of barotrauma (e.g., Neitzel et al. 2000, Abernathy et al. 2001, Guensch et

203 al. 2002, Deng et al. 2011, Casper et al. 2012, Brown et al. 2013, Brown et al. 2014); however, results can

204 be difficult to compare across studies, stressors, or species. These difficulties are especially true when a

205 visual assessment is broken down into an intensity model, such as "no injury, minor injury, or major

206 injury," which can be highly subjective, although strict guidelines can aid evaluation (Guensch et al.

207 2002, Morrissey et al. 2005, Gravel and Cooke 2008). Additional analytical tools for injury assessment 
include fluorescence of damaged epithelial tissue (Noga and Udomkusonsri 2002, Davis and Ottmar 2006) and histological examination (Elston et al. 1997, Brown et al. 2009, Brown et al. 2012), but use of these tools is limited in comparison to the methods described below.

212 Injury assessment indices can give context to visual assessments and allow for standardization across

213 studies. For example, McKinstry et al. (2007) created a classification system to predict survival outcomes

214 for juvenile Chinook salmon exposed to rapid decompression simulating turbine passage. In accordance

215 with the metric the fish is categorized as mortally injured if it dies immediately or any one of eight

216 injuries are observed: ruptured swim bladder; exopthalmia; blood or bile secretions from the vent; emboli

217 in the gills; emboli in the pelvic fins; or hemorrhaging in the pericardium, liver, or kidney (McKinstry et

218 al. 2007). The eight mortal injuries were shown to be associated with mortality prior to inclusion in the

219 mortal injury metric. Mortal injuries can be identified for a species of interest by systematic exposure to a

220 broad range of the stressor (e.g., range of shear forces that a fish may be exposed to during hydro-facility

221 passage). Exposed fish can be held for a prescribed period of time to determine delayed mortality rates

222 and to determine the types of injuries observed for fish that survived and died during the post-treatment

223 holding period. Once the mortal injuries are validated for the species of interest, the need for prolonged

224 observation to determine delayed mortality is eliminated (Brown et al. 2012).

226 Another classification system for identifying damage to fish due to rapid decompression was derived by

227 Halvorsen et al. (2012). Their main model (the Fish Index of Trauma [FIT]) was used to quantify damage

228 associated with pile driving and has similar endpoints to the McKinstry et al. (2007) mortal injury metric.

229 The FIT model attaches weighted numerical scoring to the presence or absence of 22 different injuries

230 (e.g., hematomas, hemorrhages, swim bladder rupture; Halvorsen et al. 2012). The FIT model then

231 combines fish damage into a single value, referred to as the Response Weighted Index (RWI), which is

232 the weighted sum of the injuries, with weighting based on the severity of the injury type (Halvorsen et al.

233 2012). Similar to the McKinstry et al. (2007) mortal injury metric, the FIT model was created using 
234 juvenile Chinook salmon exposed to rapid decompression, and its applicability to other life stages, 235 species, and stressors has not been investigated (Halvorsen et al. 2012).

Injury assessments provide a number of benefits over other methods used to evaluate the effects of hydro-

238 facility passage on fish. In part, this is because visual assessments can be done with limited resources;

239 although in field studies, visual assessment does necessitate recapture (e.g, Stokesbury and Dadswell

240 1991; Mathur et al. 1996). With strict guidelines to reduce subjectivity and with further development and

241 validation of indices such as the McKinstry et al. (2007) mortal injury metric and Halvorsen et al. (2012)

242 FIT model to a variety of species and stressors, visual assessment indices can provide the widespread

243 comparability needed to be a key metric in assessing the impacts of downstream hydro-facility passage on

244 fish. Injury assessments, however, have the potential to be misleading when multiple sub-lethal injuries

245 compound (as can occur during hydroturbine passage in a field setting) to create a larger impact on a fish,

246 such as mortality, and this fact needs to be kept in mind during the creation and validation of injury

247 indices.

\section{Physiological Markers}

249 Physiological markers can provide insight into both near and long term influences of hydro facility

250 passage on fish. The range of available physiological markers is vast, as outlined by Hasler et al. (2009),

251 and includes measures of endocrine concentration, gene expression, enzymatic activity, protein

252 breakdown products, and blood chemistry, among others (e.g., Matsche and Gibbons 2012). The most

253 common physiological markers are stress indicators derived from blood chemistry, and include measures

254 of osmolality, cortisol, lactate, and glucose (Wendelaar Bonga 1997). Stress indicators, such as plasma

255 cortisol, have been used to compare the responses of fish through different passage structures (e.g., Weber

256 et al., 2002, Mesa et al., 2013). These indicators are advantageous as they can be assessed from a non-

257 lethal blood sample, are quantitative and less subjective than injury assessments, and some can be

258 measured in the field using handheld meters (e.g., glucose and lactate; Stoot et al. 2014). 
260 Genomic tools, such as polymerase chain reaction (PCR) and microarrays, have been used more widely in

261 recent years to explore the consequences of environmental stressors on individual organisms and

262 populations (, Gerwick et al. 2007, Gonzalez et al. 2007, Talbot et al. 2009, Ingerslev et al. 2010, Qi et al.

263 2011, Pribyl et al. 2012, Andrews et al. 2014). While not used extensively in fish passage research,

264 genomic tools offer the benefit of being able to separate specific responses of interest such as those

265 pertaining to a single organ (e.g., the liver [Gerwick et al. 2007, Talbot et al. 2009, Pribyl et al. 2012]) or

266 a single type of response (e.g., immune system [Ingerslev et al. 2010]). In fish passage research, genomic

267 tools could be used as indicators to determine extent of injury and time to recovery in response to

268 exposure to hydro facility related stressors. For example, Pribyl et al. (2012) quantified expression of

269 genes involved in innate immune responses for black rockfish (Sebastes melanops) in response to

270 barotrauma exposure and recovery following exposure.

271

272 Assessments of enzymatic activity and associated breakdown products have similar advantages and

273 disadvantages as genomic tools and can also be used to focus on specific types of responses and injuries

274 (e.g., nutrition, tissue damage, and lipid metabolism [Wagner and Congleton 2004]; traumatic brain injury

275 [Miracle et al. 2009]). Additionally, physiological tools can be used in predicting survival of individuals

276 and populations (Cooke and O'Connor 2010); however, physiological indicators need to be ecologically

277 relevant and linked to fitness. One reason that physiological tools have been underutilized in fish passage

278 research may be the substantial investments required in both time and instrumentation to develop the

279 cause-and-effect relationships.

280

281 The diversity of physiological markers used to assess stress responses highlights the versatility of

282 physiological tools. In addition, with the high emphasis on human research, the utility of physiological

283 tools and markers is growing rapidly. Many of these tools have the potential to be applied to fish-related

284 research. For example, human traumatic brain injury research has identified several diagnostic protein 
markers, one of which is alpha II-spectrin. This marker was then used in fish to evaluate traumatic brain

286 injury in fish that passed through a hydro-facility (Miracle et al. 2009). For many of the physiological

287 markers, however, their specificity and high cost to measure makes them less useful in considering a

288 metric that can be applied across numerous studies for a wide variety of species. A single marker may not

289 provide sufficient diagnostic information; instead a suite of physiological markers may be necessary. It is

290 necessary to consider what factors, aside from stress, can alter each physiological marker and influence

291 the signal. The blood chemistry stress indices described above are the most widely applicable, low-cost

292 physiological markers and can be used across species. The direct comparability of different values

293 derived from blood chemistry would need to be validated across species and ages before widespread use

294 could occur. An effort to categorize degrees of stress using ranges of values for each species and age

295 group or linking the responses to an ecologically relevant endpoint, such as mortality, would facilitate the

296 comparability of physiological indicators.

\section{Behavior}

298 Behavioral changes (both voluntary and involuntary responses to stimuli) in fish are often assessed in 299 conjunction with other metrics, particularly as a component of injury or mortality assessments where 300 behaviors such as the loss of equilibrium or lethargy are considered indicators of injury or predictive of 301 mortality (e.g., Neitzel et al. 2000, Guensch et al. 2002, Davis and Ottmar 2006, Diamond and Campbell

302 2009). Such combinations of metrics can be a successful way to maximize behavioral change information 303 and can be expanded to assess the effects of passage through hydro-facilities.

305 Diamond and Campbell (2009), for example, created a condition index to predict delayed mortality of red 306 snapper (Lutjanus campechanus) that were captured in recreational fisheries. When captured at depth and 307 brought to the surface, these fish are exposed to decompression and can sustain barotraumas similar to 308 those observed in fishes that are exposed to rapid decompression during hydro-facility passage. The 309 condition index is based on the observation of a series of injuries (i.e., bleeding, protruding intestines, 
everted stomach, exopthalmia) and behaviors (i.e., problems with submergence within a cage, ability to

311 flap normally, and ability to gill normally). This index is partially similar to those derived solely from the

312 observations of injuries (i.e., mortal injury [McKinstry et al. 2007]; FIT model [Halverson et al. 2012]) in

313 that the variables included in the condition index must be validated for each species and life stage. Once

314 established, such an index removes the need to hold fish for prolonged periods of time to assess delayed

315 mortality.

317 A recent tool for behavioral assessment is the reflex action mortality predictor (RAMP) curve, which

318 relies on a brief ( $<30$ seconds) analysis of fish reflexes (e.g., orientation, startle response, gag response,

319 vestibular-ocular response, and body flex upon restraint [Davis 2010]) after exposure to a stressor.

320 Reflexes are an innate response to an environmental change and have a direct ecological relevance for

321 fitness. Davis (2010) demonstrated that assessment of the reflexes in fish exposed to a specific stressor

322 can be used to predict mortality. Using this method, the reflexes known to be present in an unstressed

323 fish are assessed immediately following exposure to a stressor. These results correspond to a RAMP

324 score (number of reflexes absent divided by the number of reflexes examined) between 0 and 1 , with 0

325 indicating no reflex impairment and 1 indicating complete reflex impairment. This score can be

326 compared to a predetermined RAMP curve to predict the likelihood of mortality for an individual.

327 The speed, low cost, and whole-organism evaluation of reflex assessment makes it an appealing tool, but

328 like many of the metrics mentioned above, a RAMP curve (including key reflexes to evaluate and the

329 relationship between impairment and mortality) would need to be established for each species and age

330 group of interest and potentially each stressor (Davis 2010).

332 Behavioral metrics are used less frequently on their own to assess the effects of hydro-facility passage and

333 can include observations of swimming ability, disorientation, lethargy, predator evasion, or other simple

334 observations of change (Mesa et al. 1994; Haro et al. 1998; Tierney and Farrell 2004). Observing

335 behavioral changes can be difficult in field studies, but telemetry tools can be used to track fish and 
336 observe changes in swimming speed or location after stressor exposure (Sprankle 2005; Gravel and

337 Cooke 2008; McMichael et al. 2010).

\section{Discussion}

The selection of a metric to evaluate stressor effects involves a number of different factors including

340 logistical constraints (e.g., setting, permitting allowances), desired endpoint (i.e., end use of data,

341 comparability needed), and available resources (e.g., funds, personnel, equipment). All factors that may

342 be involved in the decision making process cannot be covered for all possible situations in this review.

343 Instead, this discussion provides an overview of some of the important concepts and considerations that

344 should be taken into account during the decision process. Although the focus of this discussion is on

345 studies that involve evaluating the stressors associated with hydro-facility passage, these factors are

346 important in the design of experiments with a variety of focus areas.

\section{Study Setting}

348 The setting of a study can dictate or influence which metric is most appropriate to evaluate actual or

349 simulated hydro-facility passage. Laboratory studies are ideal to investigate individual stressors, allowing

350 for precise control of the intensity, duration, and type of stressors to which fish are exposed, and to utilize

351 metrics that require post-exposure evaluation, such as injury assessment, physiological markers, and some

352 behaviors (e.g., reflexes, swimming performance, predator evasion; Table 1). Laboratory apparatuses that

353 replicate specific stressors encountered during hydro-facility passage have successfully been used to test

354 the response of fish in a controlled setting. For example, Stephenson et al. (2010) described an advanced

355 system designed to test the effects of decompression on fish. The Mobile Aquatic Barotrauma Laboratory

356 (MABL) includes sophisticated chambers that expose fish to complex pressure scenarios under a range of

357 water quality parameters (e.g., total dissolved gas, temperature; Stephenson et al. 2010). Sensors in the

358 chambers allow the pressures experienced by the fish to be recorded at a sampling rate of $1,000 \mathrm{~Hz}$,

359 making the experiments repeatable. Furthermore, the MABL has been used to examine the effects of 
rapid decompression associated with hydro-turbine passage on a number of different species (e.g.,

361 juvenile Chinook salmon [Oncorhynchus tshawytscha; Brown et al. 2012]; juvenile Pacific and brook

362 lamprey [Entosphenus tridentatus and Lampetra richardonii, respectively; Colotelo et al., 2012]).

363 Similarly, EPRI (2008) designed and constructed a blade strike apparatus that allowed control of the blade

364 design and strike velocity. The system also recorded the fish orientation to the blade (i.e., dorsal, ventral,

365 side) and location of the blade strike along the body (i.e., head, mid-section, and tail region). These types

366 of experiments allow for a better understanding of the individual mechanisms of injury for fish exposed to

367 hydro-facility related stressors. However, the design and construction of apparatuses that generate these

368 exposures can require substantial capital investments and typically only expose fish to one stressor at a

369 time, which may not be representative of what fish experience during downstream movement.

371 In comparison to laboratory studies, field studies allow researchers to investigate the effects of multiple

372 stressors in a realistic hydro-facility environment, but can be logistically challenging. Additionally, field

373 studies are bound by the operating configuration of the hydro-facility, which likely cannot be altered due

374 to environmental conditions (e.g., discharge) or regulatory needs (e.g., power needs, environmental flow

375 appropriations). Mortality can be easily assessed in these settings, and technological tools, such as

376 telemetry, allow researchers to monitor survival rates post-passage, eliminating the need to recapture fish

377 (Bell and Kynard 1985; Hasler et al. 2009; McMichael et al. 2010). However, other metrics that require

378 post-passage evaluation of the fish (i.e., injury assessment, physiological markers, and behavior) may

379 necessitate the complicated task of recapturing individuals using downstream collection facilities or tools

380 such as the Hi-Z Turb'N Tag. Recapturing individuals likely subjects the fish to more stressors, which

381 may confound results (Taylor and Kynard 1985; Heisey et al. 1992). For example, neutrally buoyant,

382 externally attached transmitters can alter a fish's maximum sustainable swimming speed, which can affect

383 movement through hydro-facilities (Janak et al. 2012). Internal tags have also been shown to increase

384 barotrauma rates thus negatively biasing survival rates (Carlson et al. 2012). Additionally, the surgery

385 process (including anesthesia and implantation/attachment of the tag) may elicit a stress response for the 
fish, potentially altering behavior and survival (Jepsen et al. 2002). Thus, field studies may not be appropriate for all metrics. Logistical challenges and the need for resources to track fish survival (e.g., telemetry equipment, personnel) or recapture individuals (e.g., nets, personnel) can often make field studies more expensive than laboratory studies. Additionally, the magnitude and types of stressors that a given fish is exposed to during passage are unknown, limiting the ability to isolate the specific reasons for the response (e.g., mortality, injury, physiological markers, behavioral change). Further complicating field studies, working with protected species involves extensive permitting and monitoring take limits.

One advantage of field studies is the ability to characterize the hydro-facility environment and evaluate passage simultaneously. Environment characterization can be used to better understand the stressors that fish were exposed to during downstream passage and may allow for correlation with the effects observed.

397 Tools, such as the Sensor Fish, have been frequently used to characterize hydro-turbines and spillways 398 and can be used for such comparisons; however, the relationships between the forces captured using the 399 Sensor Fish, the conditions that fish are experiencing, and injury and mortality rates has not been studied 400 extensively (Deng et al. 2010).

\section{Comparability}

402 Although logistical concerns may appear to be the most important factor when designing a study, the comparability of the results is imperative to allow for scientific discussion, to inform hydro-facility

404 decision-making, and to be of use in a modeling context. Studies that expose fish to multiple stressors

405 simultaneously (e.g., field studies, reduced scale turbine laboratory studies) complicate comparability 406 because the magnitude and types of stressors to which the individual fish were exposed are unknown

407 (Table 1). These studies may be most helpful to evaluate passage through hydro-facilities post408 construction, whereas, studies that focus on single stressors may be more useful in identifying the 409 mechanisms and thresholds of injury information that is useful in the turbine design process (Richmond et 410 al. 2014). 
412 Comparability of results relies on three elements: the difference in response based on species/life stage,

413 the differences in methodology and endpoint within a given metric, and the ability to understand each

414 metric in a common context. The variation in response to a stressor for different species and life stages

415 requires that metrics be validated as comparable before use. The validation process would need to be

416 done so that the "minimal" and "significant" responses of the metric would be equivalent across different

417 life stages and species despite changes in assessment or categorization based on the unique needs to the

418 subset of fish. For example, a [age, species] fish with a plasma cortisol level of [level] versus a [different

419 age, same species] fish with a plasma cortisol level of [same level] may be in very different states of

420 stress response, but as long as that has been categorized in such a way that the two different plasma

421 cortisol levels correspond to different stress responses or amounts, then the metric can be used across the

422 different life stages and yield information that can be understood in a single context.

424 Comparability within categories of metrics is derived from standardization within each metric system.

425 The assessment of response must be standardized within a metric so that it can be repeated in other 426 studies knowing that the results are being determined in the same way and can thus be compared to each 427 other. Intra-metric comparability also relies on a way of relating a variety of stress effects (e.g., types of 428 injuries) from different stressors (e.g., pressure change) to each other. Using a categorization system, 429 indices, or pre-determined endpoints help to facilitate comparisons. Mortality is the simplest example 430 because there is a single, clear, non-subjective endpoint regardless of the source or extent of the response.

431 Injury assessment, physiological markers, and behavior all have the ability to be linked to a single

432 endpoint, but in order to utilize a single endpoint, the methodology of the endpoints chosen would need to 433 be consistent and able to be applied in multiple contexts. The McKinstry et al. (2007) mortal injury 434 metric and the FIT model (Halvorsen et al. 2012) are two examples of ways to create consistency within 435 injury assessment metrics. Both indices create systems of assessing injuries independent of the stressor, 
436 which allows the results within the system to be compared to each other. Expanding such indices to a

437 variety of species and life stages can allow for additional comparability.

439 The final element of comparability is cross-metric comparability so that the evaluation of a fish's

440 response to a stressor can be understood independent of the metric. Cross-metric comparability is

441 predicated on the consistency needed for intra-metric comparability but also relies on validation across

442 metrics. Multiple metrics are needed to evaluate the array of fish responses to stressors due to the

443 inherent nature of different stressors eliciting different responses, which is why cross-metric

444 comparability is also inherently complex and cannot be accounted for in its entirety (e.g., trying to

445 compare the injuries caused by blade strike to a plasma cortisol level after exposure to turbulence).

446 Cross-metric comparability can be assisted by using multiple metrics when possible in order to relate

447 indices or endpoints. If this type of validation is not possible, intensity models (e.g. "minimal" to

448 "significant" effects) can also bridge the understanding between metrics. Similar to intensity models,

449 using a fixed point of reference can also help relate different metric results. A fixed point of reference

450 could be as simple as mortality (e.g., this particular set of behaviors is generally observed before

451 mortality) to give context even if mortality does not occur in a study.

\section{Resources}

453 The resources associated with a study to evaluate the effects of hydro-facility passage on fish are highly 454 variable and depend on many factors. The study cost variability is primarily due to the setting (field or 455 laboratory), evaluation metric chosen, and whether the study relies on prior work that validates the metric 456 for the species and life stage of interest. When evaluating the resources needed for a study design, it is 457 therefore necessary to consider not only the needed resources for each individual component of the study, 458 but also the additive costs created from the specific configuration of choices (e.g., choosing to use 459 physiological indicators in a field study necessitating recapture). 
461 Overall, field studies generally require more resources than laboratory studies due to the additional

462 logistic considerations and the costs of telemetry systems, transmitters, and/or recapturing individuals

463 (Table 1). Telemetry studies also require processing and interpretation of the data collected to identify

464 survival and behaviors of fish, requiring additional resources (McMichael et al., 2010; Figure 1). In

465 comparison, laboratory studies that utilize existing fish housing and testing facilities may require fewer

466 resources (Figure 2).

467

468 The metrics evaluated in a given study can require a variety of analytical equipment, extended periods of 469 monitoring, or, for immediate mortality, no additional resources beyond observation (Table 1). The range

470 of metric-derived resources needed, therefore, typically spans from immediate mortality when no post-

471 treatment monitoring is required (less resources) to physiological markers that require tissue collection

472 supplies (e.g., blood and organ tissue), assay supplies, laboratory equipment, and additional labor to

473 process and analyze collected samples (more resources). The costs for the physiological resources can

474 quickly increase with large sample sizes, the need for pre-processing samples, and the need to further

475 develop assays if not commercially available. Delayed mortality monitoring, behavior observations, and

476 injury assessment all require post-treatment observations and fall in the middle of the range. However,

477 reliance on additional laboratory equipment (e.g., imaging technology, respirometers) can increase the

478 resources needed for injury assessment and behavior observations.

\section{$479 \quad$ Invasiveness}

480 It may not be prudent to lethally sacrifice individuals in a given study, particularly when working with 481 species of conservation concern or limited availability (Cooke 2008). This is an important consideration

482 in field studies where individuals that do not die as a result of the treatment may be released back into the 483 natural environment. For example, injury metrics often require necropsies, whereas many physiological 484 and behavior metrics can be sub-lethally assessed, allowing wild fish to be released. Furthermore, if 485 using telemetry, mortality and behavior can be assessed without resampling individuals, but telemetry 
486 requires surgery before fish are released. For laboratory studies, the importance of invasiveness may

487 relate more to the resources available for a given study (e.g., personnel, equipment, funding, time) as

488 laboratory animals are generally not permitted to be released into a natural environment. Behavior,

489 injury, and physiological markers can all require extensive post-treatment assessments of fish and

490 assessment of collected tissues (e.g., histology, assays).

491 Diagnostic Properties

492 Diagnostic examinations of fish post-exposure can be vital to understand the mechanisms of

493 injury/mortality. Injury assessments and physiological indicators allow researchers to isolate specific

494 organs or systems of the body that are affected by exposure (Table 1). Physiological indicators measure

495 specific physiological responses to a stressor (e.g., gene expression, blood chemistry). Similarly,

496 necropsies allow identification of specific types of injury (e.g., abrasions, lacerations, bruising, descaling)

497 and can isolate those to specific organs. For example, Brown et al. (2012b) identified through necropsy

498 and x-rays that the expansion and rupture of the swim bladder was the primary source of injuries for

499 juvenile Chinook salmon exposed to rapid decompression associated with hydro-turbine passage. This

500 information is important in understanding the mechanisms of injury for juvenile Chinook salmon, and it

501 can also be useful for predicting the susceptibility of other species to injury/mortality from rapid

502 decompression and may help with prioritization of other species to examine. Based on the collected

503 information, Brown et al. (2012b) suggested that fish that lack undissolved gases within their body cavity

504 (i.e., swim bladders), such as lamprey, would not be susceptible to rapid decompression. This theory was

505 supported when juvenile brook lamprey were exposed to a rapid decompression that would have resulted

506 in 97\% mortality for juvenile Chinook salmon and did not sustain any injuries (Colotelo et al. 2012).

507 Metrics that provide detail on the mechanisms of the response are particularly useful for studies that focus

508 on single stressors; however, they may provide more information than required. 
510 For studies not requiring extensive diagnostic detail, metrics involving whole body responses, such as

511 mortality and behavior, may be ideal. One advantage of measuring whole body responses is that fish can

512 be exposed to multiple stressors and the cumulative effect can be measured. For example, fish that pass

513 through hydro-turbines may be exposed to multiple stressors (e.g., blade strike, rapid decompression,

514 shear forces). Exposure to the individual stressors may not have negatively affected the fish; however,

515 the cumulative effects may be enough to alter the behavior or survival of an individual. Evaluations of

516 the performance of hydro-facilities often focus on examining the whole body responses, namely survival

517 (Skalski et al. 2010). In these studies, fish are released upstream of a hydro-facility and survival is

518 monitored through the downstream reaches of the river. In these scenarios, it may be too difficult to link

519 the specific types of effects (e.g., injuries, physiological responses) with the types and magnitude of the

520 stressors, since there are infinite possibilities.

\section{Evaluation of Metrics for Use with the Biological Performance Assessment Tool}

522 The process to design and manufacture a new hydro-turbine can be costly and require several years to

523 complete. Therefore, it is important during the design process to understand the relationship between

524 design characteristics, the physical forces that fish may experience during passage, and the likelihood of

525 negative effects for those fish (Brown et al. 2012). To assist in this role, tools, such as the BioPA tool,

526 can be used to compare the biological performance of multiple turbine designs prior to construction

527 (Richmond et al. 2014). The BioPA tool uses simulated data from computational fluid dynamics (CFD)

528 models to compute a suite of biological performance indicators (based on the probability of exposure to

529 stressors from streamtrace sampling) for each turbine design. This allows engineers and biologists to

530 identify designs and operations that will minimize the extent and magnitude of stressors that fish may be

531 exposed to during passage (Richmond et al. 2014). The BioPA tool relies on information collected from a

532 variety of sources, including the relationships between the magnitude of the stressors (dose) that occur

533 within hydro-turbines and the responses of the fish that encounter these stressors as determined in

534 laboratory experiments. While the BioPA tool currently focuses on hydro-turbine designs, the general 
535 approach may also be applicable to the design of other structures within a hydro-facility, including 536 spillways, sluiceways, and other routes that water and fish may pass through.

The dose-response relationship for juvenile Chinook salmon exposed to rapid decompression and evaluated using the mortal injury metric, as described by Brown et al. (2012a), has been successfully integrated into the BioPA tool allowing for the successful comparison of new turbine designs for Priest

541 Rapid Dam on the Columbia River (Richmond et al. 2013). However, there is a need to integrate more

542 dose-response relationships that include additional species and stressors to expand the applicability of the

543 BioPA tool. One of the most prominent reasons for the lack of integration of other studies is the lack of

544 comparability among the biological endpoints used in different studies. Many of the studies that have

545 evaluated the effects of hydro-facility passage (or examined specific stressors) have used various metrics.

546 Additionally, the physical conditions that fish are exposed to can vary substantially (e.g., rate of pressure

547 change, speed of blade strike) or may not be representative of the conditions that occur during hydro-

548 facility passage. Therefore, there is a need to identify priority metrics and provide guidance for future

549 studies with results that may be integrated into the BioPA tool.

551 The BioPA tool evaluates the probability of exposure to a certain dose of a stressor; if the dose-response 552 relationship is known for the species and stressor, the likelihood of negative effects can be calculated 553 (Richmond et al. 2014). Since these analyses are linked to specific stressors, studies that focus on 554 individual stressors would be easily transferred. Thus laboratory based studies would be the ideal study 555 setting to determine dose-response relationships. In addition, the dose-response relationship is critical for 556 evaluation tools such as HBET. With the known dose-response relationship, HBET can estimate 557 likelihood of injury to fish that might experience the exposure observed by measurement technologies 558 such as Sensor Fish, leading to reduction of the use of live fish and cost during the evaluation stage. 
560 The evaluations of hydro-facilities by regulatory agencies commonly focus on survival rates of fish that

561 pass through. Typically, the Federal Energy Regulatory Commission requests studies that evaluate

562 entrainment rates of fish through the facility during the licensing process for hydro-facilities. These

563 studies are generally coupled with survival studies to estimate the impacts that entrainment has on fish

564 populations (FERC 1995). Similarly, specific dam passage survival rates are required in the lower Snake

565 and Columbia rivers of the Pacific Northwest of the United States at hydro-facilities operated by the

566 USACE (NOAA 2008). For this reason, dose-response relationships included in the BioPA tool should

567 use mortality as a metric or should use an index that can tie to mortality (e.g., mortal injury metric

568 [McKinstry et al. 2007], condition index [Diamond and Campbell 2009], RAMP [Davis 2010]). Indices

569 have the added benefit of incorporating diagnostic information about the mechanisms and thresholds of

570 damage which is useful in identifying biological design criteria for new hydro-turbines (Trumbo et al.

$5712014)$.

572

573 Indices have additional features that make them good candidates for studies that can be incorporated into

574 the BioPA tool. Once the critical injuries or behaviors are identified and validated as predictors of

575 mortality, long term holding of individuals is no longer required, reducing the resources needed (i.e., post-

576 treatment holding). Furthermore, critical injuries or behavior provide insight on important variables to

577 look for when establishing dose-response relationships for other species. This presents an established

578 methodology to identify critical variables and increases the comparability among studies. Based on this

579 framework, future studies that establish dose-response relationships for fish exposed to hydro-turbine

580 related stressors should focus on indices that relate to mortality but also possess diagnostic properties to

581 help identify mechanisms and thresholds of damage.

\section{Conclusion}

583 With the diversity of hydro-facility passage-related effects on fish and the many factors that influence

584 study design, it is unsurprising that such a wide variety of metrics has been created or adapted to 
585 hydropower by the scientific community. The lack of comparability among metrics, however, hinders 586 applications of results and deters incorporation into design tools such as the BioPA and evaluation tools 587 such as HBET. All metrics have advantages and limitations that should be thoroughly evaluated before a 588 study is performed, however, as much as possible, a high degree of comparable metrics between studies is 589 critical for future research. Increased comparability of metrics will allow the results of future studies to 590 be more accessible for scientific discussion, informative for hydro-facility decision-making, and critical in 591 identifying mechanisms and thresholds of damage. 


\section{Acknowledgements}

593 This work was funded by the United States Department of Energy DOE Energy Efficiency and

594 Renewable Energy, Wind and Water Power Technologies Program. Pacific Northwest National

595 Laboratory is operated by Battelle for the DOE under Contract DE-AC05-76RL01830. 
596

597

598

599

600

601

602

603

604

605

606

607

608

609

610

611

612

613

614

615

616

617

618

619

620

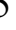

\section{References}

Abernethy, C.S., Amidan, B.G. and Čada, G. 2001. Laboratory studies of the effects of pressure and dissolved gas supersaturation on turbine-passed fish. Available from Pacific Northwest National Laboratory, Richland, WA. PNNL-13470.

Andrews, C., Payne, J. and Rise, M. 2014. Identification of a gene set to evaluate the potential effects of loud sounds from seismic surveys on the ears of fishes: a study with Salmo salar. J. Fish Biol., 84(6): 1793-1819. doi:10.1111/jfb.12398.

Bell, C.E. and Kynard, B. 1985. Mortality of adult American shad passing through a 17-megawatt Kaplan turbine at a low-head hydroelectric dam. N. Am. J. Fish Manage., 5(1): 33-38. doi:10.1577/15488659(1985)5<33:MOAASP $>2.0 . \mathrm{CO} ; 2$.

Blackwell, B.F. and Juanes, F. 1998. Predation on Atlantic salmon smolts by striped bass after dam passage. N. Am. J. Fish Manage., 18(4): 936-939. doi:10.1577/1548-

8675(1998)018<0936:POASSB>2.0.CO;2.

Brown, R.S., Ahmann, M.L., Trumbo, B.A. and Foust, J. 2012b. Fish protection: cooperative research advances fish-friendly turbine design. Hydro Rev., 31(8): 48-53.

Brown, R.S., Carlson, T.J., Gingerich, A.J., Stephenson, J.R., Pflugrath, B.D., Welch, A.E., Langeslay, M.J., Ahmann, M.L., Johnson, R.L. and Skalski, J.R. 2012a. Quantifying mortal injury of juvenile Chinook salmon exposed to simulated hydro-turbine passage. T. Am. Fish Soc., 141(1): 147-157. doi:10.1080/00028487.2011.650274. 
621 Brown, R.S., Carlson, T.J., Welch, A.E., Stephenson, J.R., Abernethy, C.S., Ebberts, B.D., Langeslay,

622 M.J., Ahmann, M.L., Feil, D.H. and Skalski, J.R. 2009. Assessment of barotrauma from rapid

623 decompression of depth-acclimated juvenile Chinook salmon bearing radiotelemetry transmitters. T. Am.

624 Fish Soc., 138(6): 1285-1301. doi:10.1577/T08-122.1.

625

626

627

628

629

Brown, R.S., Colotelo, A.H., Pflugrath, B.D., Boys, C.A., Baumgartner, L.J., Deng, Z.D., Silva, L.G., Brauner, C.J., Mallen-Cooper, M. and Phonekhampeng, O. 2014. Understanding barotrauma in fish passing hydro structures: a global strategy for sustainable development of water resources. Fisheries, 39(3): 108-122. doi:10.1080/03632415.2014.883570.

630

631

Brown, R.S., Cook, K.V., Pflugrath, B.D., Rozeboom, L.L., Johnson, R.C., McLellan, J.G., Linley, T.J.,

632 Gao, Y., Baumgartner, L.J. and Dowell, F.E. 2013. Vulnerability of larval and juvenile white sturgeon to 633 barotrauma: can they handle the pressure? Conserv. Physiol., 1(1). doi:10.1093/conphys/cot019.

634

Brown, R.S., Deng, Z.D., Cook, K.V., Pflugrath, B.D., Li, X., Fu, T., Martinez, J.J., Li, H., Trumbo, B.A. and Ahmann, M.L. 2013. A field evaluation of an external and neutrally buoyant acoustic transmitter for juvenile salmon: implications for estimating hydroturbine passage survival. PLOS One 8(10): e77744. doi:10.1371/journal.pone.0077744.

Brown, R.S., Pflugrath, B.D., Colotelo, A.H., Brauner, C.J., Carlson, T.J., Deng, Z.D. and Seaburg, A.G. 2012. Pathways of barotrauma in juvenile salmonids exposed to simulated hydroturbine passage: Boyle's

642 law vs. Henry's law. Fish. Res., 121: 43-50. doi:10.1016/j.fishres.2012.01.006.

643

644 C̆ada, G.F. 1991. Effects of hydroelectric turbine passage on fish early life stages. Available from Oak 645 Ridge National Laboratory, Oak Ridge, TN. CONF-910778-2. 
647 Čada, G.F. 2001. The development of advanced hydroelectric turbines to improve fish passage survival. 648 Fisheries, 26(9): 14-23. doi:10.1577/1548-8446(2001)026<0014:TDOAHT>2.0.CO;2.

650 Čada, G.F., Garrison, L.A. and Fisher, R.K. 2007. Determining the effect of shear stress on fish mortality 651 during turbine passage. Hydro Review, 26(7): 52.

652

653 Carlson, T. J., Brown, R.S., Stephenson, J.R., Pflugrath, B.D., Colotelo, A.H., Gingerich, A.J., Benjamin, 654 P.L., Langeslay, M.J., Ahmann, M.L., Johnson, R.L., Skalski, J.R., Seaburg, A.G. and Townsend, R.L. 655 2012. The influence of tag presence on the mortality of juvenile Chinook salmon exposed to simulated 656 hydroturbine passage: Implications for survival estimates and management of hydroelectric facilities. N. 657 Am. J. Fish. Manage. 32(2): 249-261. doi: 10.1080/02755947.2012.661384

658

659 Casper, B.M., Popper, A.N., Matthews, F., Carlson, T.J. and Halvorsen, M.B. 2012. Recovery of 660 barotrauma injuries in Chinook salmon, Oncorhynchus tshawytscha from exposure to pile driving sound. 661 Plos One, 7(6): e39593. doi:10.1371/journal.pone.0039593.

662

663 Colotelo, A.H., Pflugrath, B.D., Brown, R.S., Brauner, C.J., Mueller, R.P., Carlson, T.J., Deng, Z.D., 664 Ahmann, M.L. and Trumbo, B.A. 2012. The effect of rapid and sustained decompression on barotrauma 665 in juvenile brook lamprey and Pacific lamprey: Implications for passage at hydroelectric facilities. Fish. 666 Res., 129: 17-20. doi:10.1016/j.fishres.2012.06.001.

667

668 Cook, T.C., Hecker, G.E., Amaral, S., Stacy, P., Lin, F. and Taft, E. 2003. Pilot scale tests

669 Alden/Concepts NREC Turbine. Available from Alden Research Laboratory (US), Holden, MA.

$670 \mathrm{DOE} / \mathrm{ID} / 13733$.

671 
672 Cooke, S.J. 2008. Biotelemetry and biologging in endangered species research and animal conservation:

673 relevance to regional, national, and IUCN Red List threat assessments. Endang. Species Res., 4(1-2): 165-

674 185. doi:10.3354/esr00063.

675

676 Cooke, S.J. and O’Connor, C.M. 2010. Making conservation physiology relevant to policy makers and 677 conservation practitioners. Conserv Lett 3:159-166. doi: 10.1111/j.1755-263X.2010.00109.x

678

679 Coutant, C.C., and Whitney R.R. 2000. Fish behavior in relation to passage through hydropower turbines:

680 a review. Trans Am Fish Soc 129(2): 351-380. doi:10.1577/1548-

$681 \quad 8659(2000) 129<0351:$ FBIRTP $>2.0 . C O ; 2$

682

683 Davis, M. and Ottmar, M. 2006. Wounding and reflex impairment may be predictors for mortality in

684 discarded or escaped fish. Fish. Res., 82(1): 1-6. doi:10.1016/j.fishres.2006.09.004.

685

686

Davis, M.W., 2010. Fish stress and mortality can be predicted using reflex impairment. Fish Fish., 11(1):

687 1-11. doi:10.1111/j.1467-2979.2009.00331.x.

688

689 Deng, Z., Guensch, G.R., McKinstry, C.A., Mueller, R.P., Dauble, D.D. and Richmond, M.C., 2005.

690 Evaluation of fish-injury mechanisms during exposure to turbulent shear flow. Can. J. Fish. Aquat. Sci.,

691 62(7): 1513-1522. doi:10.1139/f05-091

692 Deng, Z., Carlson, T.J., Ploskey, G.R., Richmond, M.C. and Dauble, D.D., 2007. Evaluation of blade-

693 strike models for estimating the biological performance of Kaplan turbines. Ecol. Model., 208(2): 165-

694 176. doi:10.1016/j.ecolmodel.2007.05.019.

695 
696

697

698

699

700

701

702

703

704

705

706

707

708

709

710

711

712

713

714

715

716

717

718

719

720

Deng, Z., Carlson, T.J., Duncan, J.P., Richmond, M.C. and Dauble, D.D., 2010. Use of an autonomous sensor to evaluate the biological performance of the advanced turbine at Wanapum Dam. J. Renew. Sustain. Energy, 2(5): 053104. doi:10.1063/1.3501336.

Deng, Z., Carlson, T.J., Dauble, D.D. and Ploskey, G.R., 2011. Fish passage assessment of an advanced hydropower turbine and conventional turbine using blade-strike modeling. Energies, 4(1): 57-67. doi:10.3390/en4010057.

Deng, Z. D., J. J. Martinez, A. H. Colotelo, T. K. Abel, A. P. LeBarge, R. S. Brown, B. D. Pflugrath, R. P. Mueller, T. J. Carlson, A. G. Seaburg, R. L. Johnson, and M. L. Ahmann. 2012. Development of external and neutrally buoyant acoustic transmitters for juvenile salmon turbine passage evaluation. Fish. Res. 113(1):94-105. doi:10.1016/j.fishres.2011.08.018.

Deng, Z., Lu, J., Myjak, M.J., Martinez, J.J., Tian, C., Morris, S.J., Carlson, T.J., Zhou, D. and Hou, H., 2014. Design and implementation of a new autonomous sensor fish to support advanced hydropower development. Rev. Sci. Instrum., 85(11): 115001. doi:10.1063/1.4900543.

Diamond, S.L. and Campbell, M.D., 2009. Linking "sink or swim" indicators to delayed mortality in red snapper by using a condition index. Mar. Coast. Fish. Dynam. Manage. Ecosys. Sci., 1(1): 107-120. doi: $10.1577 / \mathrm{C} 08-043.1$.

Elston, R., Colt, J., Abernethy, S. and Maslen, W., 1997. Gas bubble reabsorption in Chinook salmon: pressurization effects. J. Aquat. Anim. Health, 9(4): 317-321. doi:10.1577/1548-

8667(1997)009<0317:GBRICS >2.3.CO;2. 
721 EPRI (Electric Power Research Institute). 2007. Investigation of hydro-turbine leading edge shapes

722 favorable to fish survival. Prepared by Alden Research Laboratory, Inc., Holden, MA, EPRI Report No.

7231012561.

724

725

EPRI. 2008. Evaluation of the effects of turbine blade leading edge design on fish survival. Prepared by Alden Research Laboratory, Inc., Holden, MA, EPRI Report No. 1014937.

EPRI. 2011. 2010 Tests examining survival of fish struck by turbine blades. Prepared by Alden Research Laboratory, Inc., Holden, MA, EPRI Report No. 1024684.FERC. 1995. Preliminary Assessment of Fish Entrainment at Hydropower Projects: A Report on Studies and Protective Measures, Volume 1.

731 Washington, DC. Paper No. DPR-10.

FERC. 1995. Preliminary Assessment of Fish Entrainment at Hydropower Projects: A Report on Studies and Protective Measures, Volume 1. Washington, DC. FERC Paper No. DPR-10. doi:10.1016/j.fsi.2006.04.003. ecologist. John Wiley \& Sons, New York, NY. pp.526.

744 K., Nielsen, M.E. and Wiegertjes, G.F., 2007. Real-time gene expression analysis in carp (Cyprinus

745 carpio L.) skin: inflammatory responses to injury mimicking infection with ectoparasites.

746 Develop.Compar. Immunol., 31(3): 244-254. doi:10.1016/j.dci.2006.06.010. 
Gravel, M.-A. and Cooke, S.J., 2008. Severity of barotrauma influences the physiological status, postrelease behavior, and fate of tournament-caught smallmouth bass. N. Am. J. Fish Manage., 28(2): 607-617. doi:10.1577/M07-013.1.

Guensch, G.R., Mueller, R.P., McKinstry, C.A. and Dauble, D.D., 2002. Evaluation of fish-injury mechanisms during exposure to a high-velocity jet. Available from Pacific Northwest National Laboratory, Richland, WA. PNNL-14173.

Halvorsen, M.B., Casper, B.M., Woodley, C.M., Carlson, T.J. and Popper, A.N., 2012. Threshold for onset of injury in Chinook salmon from exposure to impulsive pile driving sounds. Plos One, 7(6): e38968. doi:10.1371/journal.pone.0038968. Expanding the "toolbox" for studying the biological responses of individual fish to hydropower infrastructure and operating strategies. Environ. Rev., 17(NA): 179-197. doi:10.1139/A09-008. bypasses. T. Am. Fish. Soc., 127(1):118-127. doi:10.1577/1548-

Heisey, P.G., Mathur, D. and Rineer, T., 1992. A reliable tag-recapture technique for estimating turbine passage survival: application to young-of-the-year American shad (Alosa sapidissima). Can. J. Fish. 
772

773

774

775

776

777

778

779

780

781

782

783

784

785

786

787

788

789

790

791

792

793

794

795

796

797

Hou H, Z Deng, JJ Martinez, T Fu, GE Johnson, TJ Carlson, and JP Duncan. 2015. Turbine Biological Evaluation Tools and Their Applications using Sensor Fish Data. HydroVision International 2015, Portland, OR, USA.

Ingerslev, H.-C., Lunder, T. and Nielsen, M.E., 2010. Inflammatory and regenerative responses in salmonids following mechanical tissue damage and natural infection. Fish Shellfish Immun., 29(3): 440450. doi:10.1016/j.fsi.2010.05.002.

International Energy Agency, 2015. 2015 Key World Energy Statistics. Paris, France. Available from http://www.iea.org/publications/freepublications/publication/key-world-energy-statistics-2015.html [accessed 30 April 2016].

Janak, J.M., Brown, R.S., Colotelo, A.H., Pflugrath, B.D., Stephenson, J.R., Deng, Z.D., Carlson, T.J. and Seaburg, A.G., 2012. The effects of neutrally buoyant, externally attached transmitters on swimming performance and predator avoidance of juvenile Chinook salmon. T. Am. Fish. Soc., 141(5): 1424-1432. doi:10.1080/00028487.2012.688915.

Jepsen, N., Koed, A., Thorstad, E. and Baras, E., 2002. Surgical implantation of telemetry transmitters in fish: how much have we learned? In: Developments in Hydrobiology: Aquatic Telemetry. Edited by E. Thorstad, I. Fleming and T. Næsje, Springer Netherlands, pp. 239-248.

Kao, S. C., R. A. McManamay, K. M. Stewart, N. M. Samu, B. Hadjerioua, S. T. DeNeale, D. Yeasmin, M. Fayzul, K. Pasha, A. A. Oubeidillah, and B. T. Smith. 2014. New Stream-Reach Development: A Comprehensive Assessment of Hydropower Energy Potential in the United States. Prepared by Oakridge National Laboratory for the US Department of Energy, Washington, DC. GPO DOE/EE-1063. 
798 Mathur, D., Heisey, P.G., Euston, E.T., Skalski, J.R. and Hays, S., 1996. Turbine passage survival 799 estimation for chinook salmon smolts (Oncorhynchus tshawytscha) at a large dam on the Columbia River.

800 Can. J. Fish. Aquat. Sci., 53(3): 542-549. doi: 10.1139/f95-206.

801

802 Matsche, M. A., and J. Gibbons. 2012. Annual variation of hematology and plasma chemistry in 803 shortnose sturgeon, Acipenser brevirostrum, during a dam-impeded spawning run. Fish Physiol.

804 Biochem., 38(6):1679-1696. doi:10.1007/s10695-012-9664-7.

805

806 McKinstry, C., Carlson, T. and Brown, R., 2007. Derivation of a mortal injury metric for studies of rapid 807 decompression of depth-acclimated physostomous fish. Available from Pacific Northwest National 808 Laboratory, Richland, WA. PNNL-17080.

809

810 McMichael, G.A., Eppard, M.B., Carlson, T.J., Carter, J.A., Ebberts, B.D., Brown, R.S., Weiland, M., 811 Ploskey, G.R., Harnish, R.A. and Deng, Z.D., 2010. The juvenile salmon acoustic telemetry system: a 812 new tool. Fisheries, 35(1): 9-22. doi:10.1577/1548-8446-35.1.9.

813

814 Mesa, M.G., 1994. Effects of multiple acute stressors on the predator avoidance ability and physiology of 815 juvenile Chinook salmon. T. Am. Fish. Soc., 123(5): 786-793. doi:10.1577/1548-

$816 \quad 8659(1994) 123<0786:$ EOMASO $>2.3 . \mathrm{CO} ; 2$.

817

818 Mesa, M.G., Gee, L.P., Weiland, L.K. and Christiansen, H.E., 2013. Physiological responses of adult 819 rainbow trout experimentally released through a unique fish conveyance device. N. Am. J. Fish Manage., 820 33(6): 1179-1183. doi:10.1080/02755947.2013.833560.

821 
822 Metcalfe, J. D. and G. P. Arnold. 1997. Tracking fish with electronic tags. Nature

$823 \quad 387(6634): 665-666$.

824

825 Miracle, A., Denslow, N.D., Kroll, K.J., Liu, M.C. and Wang, K., 2009. Spillway-induced

826 salmon head injury triggers the generation of brain alphaII-spectrin breakdown product

827 biomarkers similar to mammalian traumatic brain injury. PloS one, 4(2).

828 doi:10.1371/journal.pone.0004491.

829

830 Morrissey, M.B., Suski, C.D., Esseltine, K.R. and Tufts, B.L., 2005. Incidence and physiological

831 consequences of decompression in smallmouth bass after live-release angling tournaments. T.

832 Am. Fish. Soc., 134(4): 1038-1047. doi:10.1577/T05-010.1.

833

834 Muir, J., 1959. Passage of young fish through turbines. Proc. Amer. Soc. Civ. Eng. (Power

835 Division), 85(1): 23-46.

836

837 Navarro, J.E., McCauley, D.J. and Blystra, A.R., 1996. Turbine passage at four low-head

838 hydroelectric facilities in northeast Michigan. N. Am. J. Fish Manage., 16(1): 182-191.

839 doi:10.1577/1548-8675(1996)016<0182:TPAFLH>2.3.CO;2.

840

841 Neitzel, D.A., Dauble, D.D., Čada, G., Richmond, M.C., Guensch, G.R., Mueller, R.P., Abernethy, C.S.

842 and Amidan, B., 2004. Survival estimates for juvenile fish subjected to a laboratory-generated shear

843 environment. T. Am. Fish. Soc., 133(2): 447-454. doi:10.1577/02-021. 
845 Neitzel, D.A., Richmond, M.C., Dauble, D.D., Mueller, R.P., Moursund, R.A., Abernethy, C.S., Guensch, 846 G.R. and Čada, G., 2000. Laboratory studies on the effects of shear on fish. Available from Pacific 847 Northwest National Laboratory, Richland, WA. PNNL-13323.

848

849 NOAA (National Oceanic and Atmospheric Administration). 2008. Consultation on Remand for 850 Operation of the Federal Columbia River Power System, 11 Bureau of Reclamation Projects in the 851 Columbia Basin and ESA Section 10(a)(I)(A) Permit for Juvenile Fish Transportation Program [Revised 852 and reissued pursuant to court order, NWF v. NMFS, Civ. No. CV 01-640-RE (D. Oregon)], NOAA 853 National Marine Fisheries Service, Northwest Region, Seattle, Washington.

Noga, E. and Udomkusonsri, P., 2002. Fluorescein: a rapid, sensitive, nonlethal method for detecting skin 856 ulceration in fish. Vet. Pathol. Online, 39(6): 726-731. doi:10.1354/vp.39-6-726.

Pracheil, B.M., C. R. DeRolph, C.R., Schramm, M.P., and Bevelhimer, M.S., In Press. A fish-eye view of 859 riverine hydropower systems: The current understanding of the biological response to turbine passage. Rev. Fish Biol. and Fish., 000:000-000.

861

862 Pribyl, A., Schreck, C., Parker, S. and Weis, V., 2012. Identification of biomarkers indicative of 863 barotrauma and recovery in black rockfish Sebastes melanops. J. Fish Biol., 81(1): 181-196. doi: $864 \quad 10.1111 /$ j.1095-8649.2012.03322.x.

865

866 Qi, Z.-H., Liu, Y.-F., Wang, W.-N., Wu, X., Xin, Y., Lu, Y.-F. and Wang, A.-L., 2011. Molecular 867 characterization and functional analysis of a complement $\mathrm{C} 3$ molecule in the orange-spotted grouper 868 (Epinephelus coioides). Fish Shellfish Immun., 31(6): 1284-1290. doi:10.1016/j.fsi.2011.09.018. 
870

871

872

873

874

875

876

877

878

879

880

881

882

883

884

885

886

887

888

889

890

891

892

893

Richmond, M. C., J. A. Serkowski, L. L. Ebner, M. Sick, R. S. Brown, and T. J. Carlson. 2014.

Quantifying barotrauma risk to juvenile fish during hydro-turbine passage. Fish. Res. 154:152-164. doi:10.1016/j.fishres.2014.01.007.

Skalski, J.R., Townsend, R.L., Steig, T.W. and Hemstrom, S., 2010. Comparison of two alternative approaches for estimating dam passage survival of salmon smolts. N. Am. J. Fish Manage., 30(3): 831839. doi:10.1577/M09-103.1.

Sprankle, K., 2005. Interdam movements and passage attraction of American shad in the lower Merrimack River main stem. N. Am. J. Fish Manage., 25(4): 1456-1466. doi:10.1577/M04-049.1.

Stephenson, J.R., Gingerich, A.J., Brown, R.S., Pflugrath, B.D., Deng, Z., Carlson, T.J., Langeslay, M.J., Ahmann, M.L., Johnson, R.L. and Seaburg, A.G., 2010. Assessing barotrauma in neutrally and negatively buoyant juvenile salmonids exposed to simulated hydro-turbine passage using a mobile aquatic barotrauma laboratory. Fish. Res., 106(3): 271-278. doi:10.1016/j.fishres.2010.08.006.

Stier, D.J. and Kynard, B., 1986. Use of radio telemetry to determine the mortality of Atlantic salmon smolts passed through a 17-MW Kaplan turbine at a low-head hydroelectric dam. T. Am. Fish. Soc., 115(5): 771-775. doi:10.1577/1548-8659(1986)115<771:UORTTD>2.0.CO;2.

Stokesbury, K.D. and Dadswell, M.J., 1991. Mortality of juvenile clupeids during passage through a tidal, low-head hydroelectric turbine at Annapolis Royal, Nova Scotia. N. Am. J. Fish Manage., 11(2): 149154. doi:10.1577/1548-8675(1991)011<0149:MOJCDP>2.3.CO;2. 
894 Stoot, L.J., Cairns, N.A., Cull, F., Taylor, J.J., Jeffrey, J.D., Morin, F., Mandelman, J.W., Clark, T.D., and

895 Cooke, S.J., 2014. Use of portable blood physiology point-of-care devices for basic and applied research

896 on vertebrates - a review. Conserv. Physiol., 2: cou011. doi: 10.1093/conphys/cou011.

Talbot, A.T., Pottinger, T.G., Smith, T.J. and Cairns, M.T., 2009. Acute phase gene expression in rainbow trout (Oncorhynchus mykiss) after exposure to a confinement stressor: a comparison of pooled and 900 individual data. Fish Shellfish Immun., 27(2): 309-317. doi:10.1016/j.fsi.2009.05.016.

902 Taylor, R.E. and Kynard, B., 1985. Mortality of juvenile American shad and blueback herring passed 903 through a low-head Kaplan hydroelectric turbine. T. Am. Fish. Soc., 114(3): 430-435. doi:10.1577/1548904 8659(1985)114<430:MOJASA>2.0.CO;2.

905

Tierney, K. and Farrell, A., 2004. The relationships between fish health, metabolic rate, swimming 907 performance and recovery in return-run sockeye salmon, Oncorhynchus nerka (Walbaum). J. Fish Dis., 908 27(11): 663-671. doi:10.1111/j.1365-2761.2004.00590.x.

909

910 Trumbo, B.A., Ahmann, M.L., Renholds, J.F., Brown, R.S., Colotelo, A.H. and Deng, Z., 2014.

911 Improving hydroturbine pressures to enhance salmon passage survival and recovery. Rev. Fish Biol.

912 Fisher., 24(3): 955-965. doi: 10.1007/s11160-013-9340-8.

913

914 Turnpenny, A. 1998. Mechanisms of fish damage in low-head turbines: an experimental appraisal. In Fish 915 migration and fish bypasses. Edited by M. Jungwirth, S. Schmutz, and S. Weiss. Fishing News Books, 916 Blackwell Science Ltd., Oxford, UK. pp. 300-314. 
US Energy Information Administration. 2014. International Energy Statistics. Available from

919 http://www.eia.gov/cfapps/ipdbproject/iedindex3.cfm?tid=2\&pid=33\&aid=12\&cid=regions\&syid=2005\& 920 eyid=2011\&unit=BKWH [accessed 15 October 2015].

Wagner, T. and Congleton, J.L., 2004. Blood chemistry correlates of nutritional condition, tissue damage, and stress in migrating juvenile chinook salmon (Oncorhynchus tshawytscha). Can. J. Fish. Aquat. Sci., 61(7): 1066-1074. doi:10.1139/f04-050.

Weber, E.D., Borthwick, S.M. and Helfrich, L.A., 2002. Plasma cortisol stress response of juvenile

927 Chinook salmon to passage through Archimedes lifts and a hidrostal pump. N. Am. J. Fish Manage., 928 22(2): 563-570. doi:10.1577/1548-8675(2002)022<0563:PCSROJ >2.0.CO;2.

Wendelaar Bonga, S.E., 1997. The stress response in fish. Physiol. Rev., 77(3): 591-625. PMID: 9234959.

Wertheimer, R.H., 2007. Evaluation of a surface flow bypass system for steelhead kelt passage at

940 Armbruster, J., Thieme, M.L., Petry, P., Zuanon, J., Vilara, G.T., Snoeks, J., Ou, C., Rainboth, W.,

941 Pavanelli, C.S., Akama, A., Soesbergen, A.V., and Saenz, L. 2016. Balancing Hydropower and

942 Biodiversity in the Amazon, Congo, and Mekong. Science 351(6269): 128-129. doi:

$943 \quad 10.1126 /$ science.aac7082. 
944

945 Zarfl, C., Lumsdon, A.E., Berlekamp, J., Tydecks, L., and Tockner, K., 2015. A global boom in

946 hydropower dam construction. Aquat Sci 77:161-170. doi: 10.1007/s00027-014-0377-0.

947

948 Zydlewski, J., Zydlewski, G. and Danner, G.R., 2010. Descaling injury impairs the osmoregulatory ability

949 of Atlantic salmon smolts entering seawater. T. Am. Fish. Soc., 139(1): 129-136. doi:10.1577/T09-054.1 
1 Tables

2 Table 1. A summary of different available metrics (i.e., mortality, injury, physiological markers, behavior) and rankings with regard to 3 the resources needed, invasiveness, comparability among stressors and species, and diagnostic properties. Metrics are ranked on a 4 scale from 0 to 5 , with 0 being the least favorable and 5 being the most favorable. 


\begin{tabular}{|c|c|c|c|c|c|c|c|}
\hline $\begin{array}{l}\text { Study } \\
\text { Setting }\end{array}$ & Metric & $\begin{array}{l}\text { Resources } \\
\text { Needed }\end{array}$ & Invasiveness & $\begin{array}{c}\text { Comparability } \\
\text { Among Stressors } \\
\end{array}$ & $\begin{array}{l}\text { Comparability } \\
\text { Among Species }\end{array}$ & $\begin{array}{l}\text { Diagnostic } \\
\text { Properties }\end{array}$ & Ideal Studies \\
\hline \multirow{4}{*}{$\mathrm{Lab}$} & Mortality & 2 & 2 & 5 & 5 & 3 & $\begin{array}{l}\text { Exposure to controlled stressors; need to } \\
\text { understand whole body responses }\end{array}$ \\
\hline & Injury & 0 & 0 & 4 & 4 & 5 & $\begin{array}{l}\text { Exposure to controlled stressors; need to } \\
\text { understand mechanisms of injury/mortality }\end{array}$ \\
\hline & $\begin{array}{l}\text { Physiological } \\
\text { Markers }\end{array}$ & 0 & 1 & 4 & 4 & 5 & $\begin{array}{l}\text { Exposure to controlled stressors; need to } \\
\text { understand mechanisms of injury/mortality }\end{array}$ \\
\hline & Behavior & 1 & 2 & 4 & 4 & 4 & $\begin{array}{l}\text { Exposure to controlled stressors; need to } \\
\text { understand whole body responses }\end{array}$ \\
\hline $\begin{array}{l}\text { Study } \\
\text { Setting }\end{array}$ & Metric & $\begin{array}{l}\text { Resources } \\
\text { Needed }\end{array}$ & Invasiveness & $\begin{array}{l}\text { Comparability } \\
\text { Among Studies }\end{array}$ & $\begin{array}{l}\text { Comparability } \\
\text { Among Species }\end{array}$ & $\begin{array}{l}\text { Diagnostic } \\
\text { Properties }\end{array}$ & $\begin{array}{c}\text { Ideal Studies } \\
\end{array}$ \\
\hline \multirow{4}{*}{ Field } & Mortality & 1 & 1 & 00 & 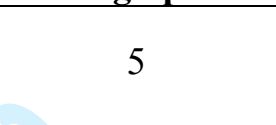 & 3 & $\begin{array}{l}\text { Exposure to multiple stressors in realistic } \\
\text { environment; need to understand whole body } \\
\text { responses }\end{array}$ \\
\hline & Injury & 0 & 0 & 3 & 4 & 3 & $\begin{array}{l}\text { Exposure to multiple stressors in realistic } \\
\text { environment; need to understand types of } \\
\text { injury/mortality }\end{array}$ \\
\hline & $\begin{array}{l}\text { Physiological } \\
\text { Markers }\end{array}$ & 0 & 1 & 3 & 4 & 3 & $\begin{array}{l}\text { Exposure to multiple stressors in realistic } \\
\text { environment; need to understand types of } \\
\text { injury/mortality }\end{array}$ \\
\hline & Behavior & 0 & 2 & 3 & 4 & 3 & $\begin{array}{l}\text { Exposure to multiple stressors in realistic } \\
\text { environment; need to understand whole body } \\
\text { responses }\end{array}$ \\
\hline
\end{tabular}




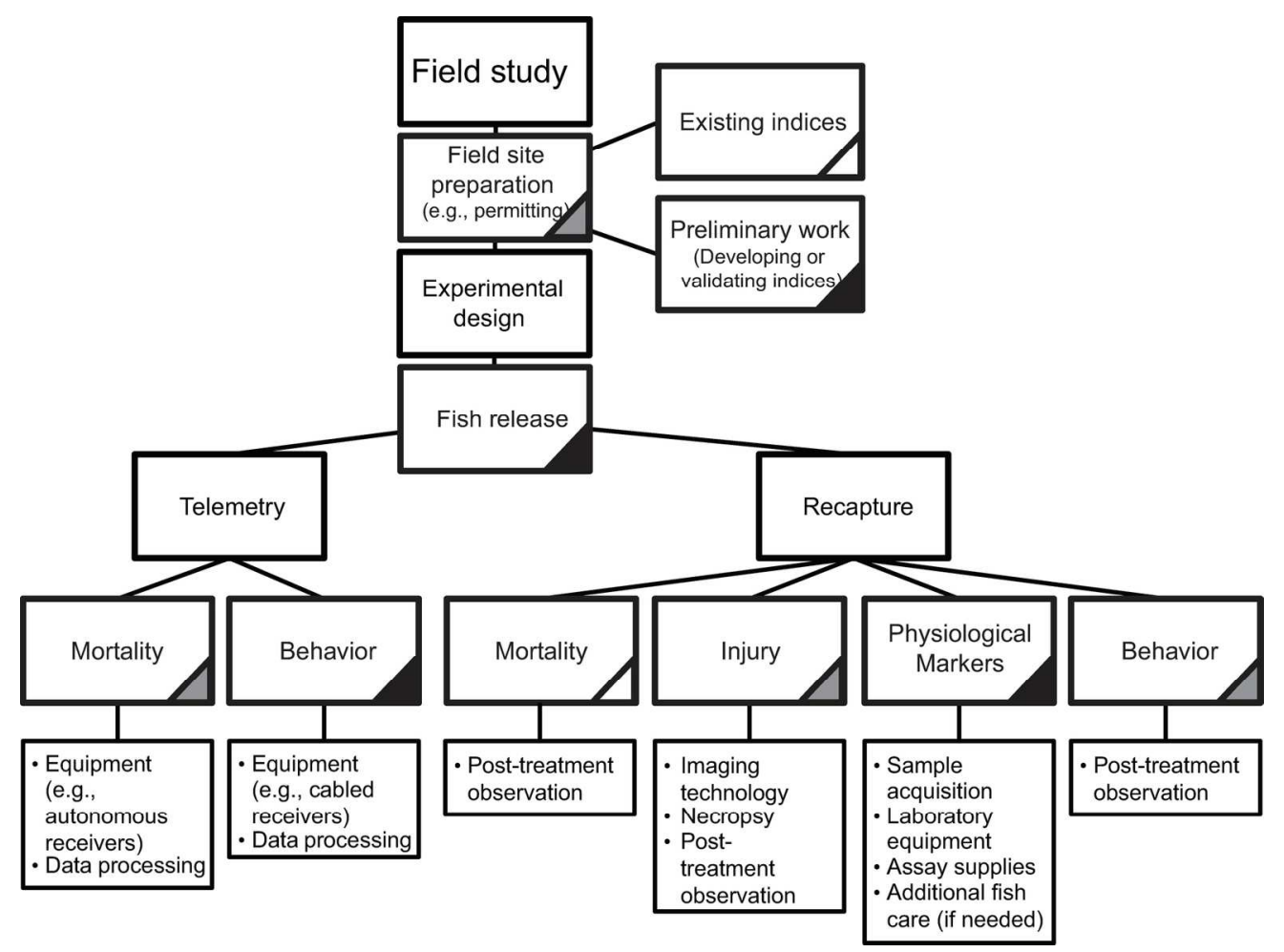

Figure 1. Factors to consider when planning a field study including the sampling method (i.e., telemetry vs. recapture) and the metric (i.e., mortality, injury, physiological markers, behavior). Shading in the corners corresponds to a high (black), medium (gray), or low (white) amount of resources required.

$161 \times 120 \mathrm{~mm}(300 \times 300$ DPI $)$ 


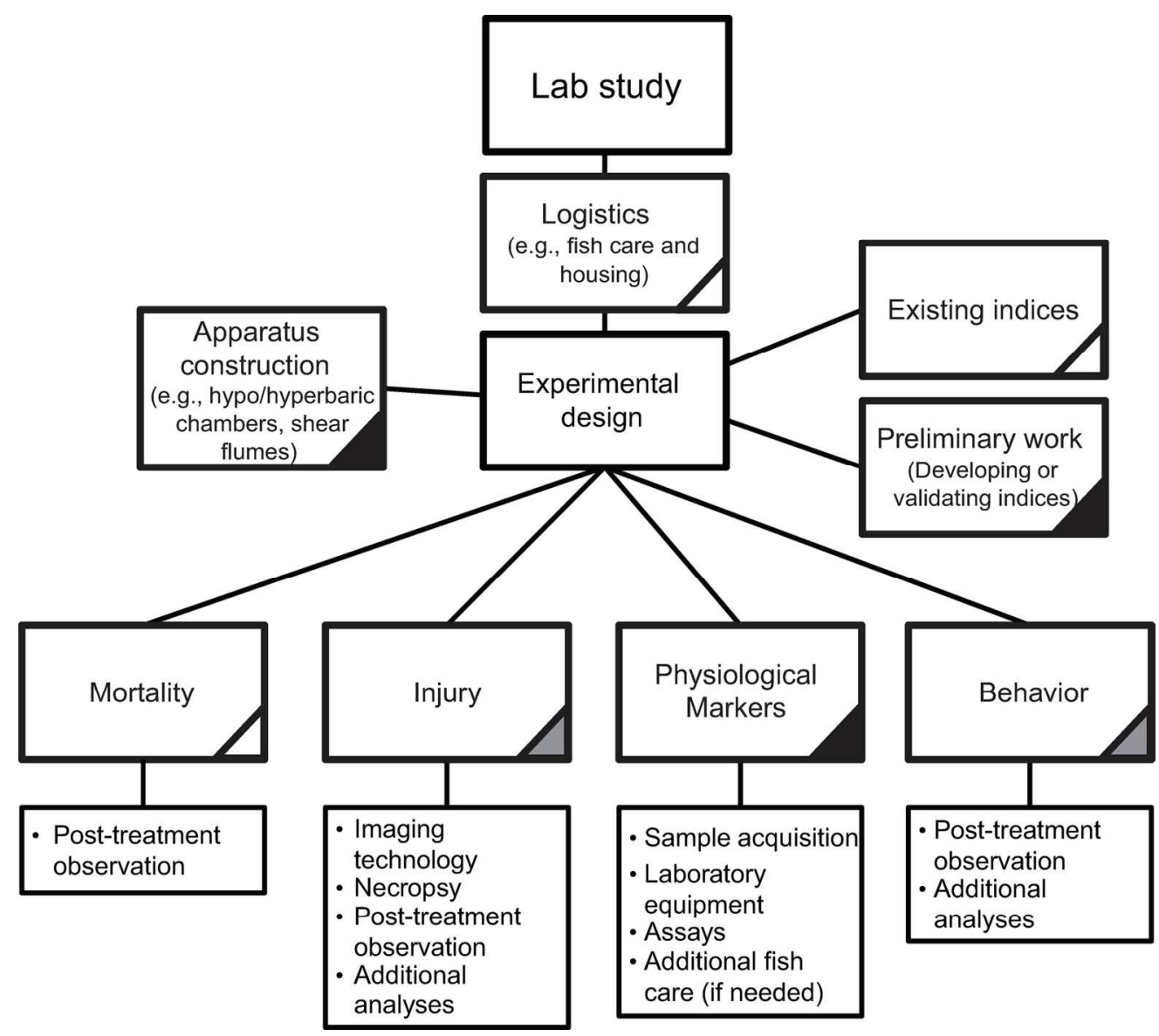

Figure 2. Factors to consider when planning a laboratory study including the metric (i.e., mortality, injury, physiological markers, behavior). Shading in the corners corresponds to a high (black), medium (gray), or low (white) amount of resources required.

$$
153 \times 137 \mathrm{~mm}(300 \times 300 \text { DPI) }
$$

